\title{
The Role of Temporary Agency Employment in Tight Labor Markets
}

\author{
Upjohn Institute Staff Working Paper 01-73
}

\author{
by \\ Susan N. Houseman \\ W.E. Upjohn Institute for Employment Research \\ Arne L. Kalleberg \\ University of North Carolina-Chapel Hill \\ George A. Erickcek \\ W.E. Upjohn Institute for Employment Research
}

December 2000

last revision, January 2003

This research was supported with a grant from the Russell Sage Foundation. We wish to thank Lillian Vesic-Petrovic and Peter Einaudi for outstanding research assistance and Claire Black for her transcription of all interviews. David Autor, Peter Cappelli, and two anonymous referees provided particularly helpful suggestions on earlier drafts of this paper. 


\title{
The Role of Temporary Agency Employment in Tight Labor Markets
}

\begin{abstract}
This paper examines the reasons why employers used and even increased their use of temporary help agencies during the tight labor markets of the 1990s. Based on case study evidence from the hospital and auto supply industries, we evaluate various hypotheses for this phenomenon. In high-skilled occupations, our results are consistent with the view that employers paid substantially more to agency help to avoid raising wages for their regular workers and to fill vacancies while they recruited workers for permanent positions. In low-skilled occupations, our evidence suggests that temporary help agencies facilitated the use of more "risky" workers by lowering their wages and benefits and the costs associated with turnover. The use of agency temporaries in both high- and low-skilled occupations reduced the pressure on companies to raise wages for existing employees, and thereby may have contributed to the stagnant wage growth and low unemployment observed in the 1990s.
\end{abstract}


Temporary agency employment expanded steadily during the 1990s. According to Bureau of Labor Statistics establishment data, employment in help supply services, which primarily comprises temporary help agencies, increased from 1.2 percent of paid employment in 1990 to 2.6 percent in 2000. The share in temporary agency employment grew throughout this period of strong economic expansion and very low unemployment despite the fact that the majority of temporary agency workers express a desire for regular, permanent jobs (Cohany 1998). The preference for regular employment among most agency temporaries has led many to conclude that the growth of the share in temporary employment in the 1990s was most likely driven by employer demand. In this paper, we provide insights into why employers heavily rely on temporary agency workers in tight labor markets based on evidence from two industries: hospitals and auto supply manufacturers.

The fact that the share in temporary agency employment moves procyclically has long been observed. The most common explanation for this pattern is that companies use agency temporaries to handle demand variability and to buffer core workers during downturns (Mangum, Mayall, and Nelson 1985; Abraham 1988; Kandel and Pearson 2001). Because agency temporaries are the first to be laid off in a recession, we would expect the share in temporary employment to rise during expansions and fall during recessions.

Nevertheless, it is hard to understand why, in the aggregate, the share in temporary employment would continue to grow strongly after almost a decade of expansion if firms were simply using temporaries to buffer core workers against an anticipated downturn. Indeed, evidence from employer surveys, (Abraham 1988, 1990; Houseman 2001b) suggests the importance of other factors, including difficulty in finding qualified workers on their own and the desire to screen workers for permanent positions. The hypothesis that, in tight labor markets, companies are filling vacancies with temporary 
agency workers while they recruit employees and are sometimes recruiting employees from the ranks of agency temporaries is strongly supported by our case study evidence.

One theme developed in this paper is that the use of agency temporaries in tight labor markets relieved pressure on companies to raise wages of regular employees. During the 1990s, the U.S. economy experienced low wage growth coupled with low unemployment rates. ${ }^{1}$ Although temporary agency employment still accounts for a relatively small share of paid employment, the growth in temporary employment accounted for 10 percent of net employment growth in the economy during the 1990s. If workers face costs in switching employers and internal labor market rules characterize wage setting for workers with some tenure on the job, then market forces primarily influence wage levels by affecting the wages of new entrants. ${ }^{2}$ Thus, it is reasonable to hypothesize some connection between the rapid growth in temporary agency employment, slow aggregate wage growth, and low unemployment. Indeed, Katz and Krueger (1999) present evidence that states with a greater presence of temporary agency employment experienced lower wage growth in the 1990s and that the lower wage growth associated with the growth in temporary employment may have accounted for up to a 0.4-percentage-point reduction in the unemployment rate. A major contribution of this paper is to improve our understanding of the mechanisms by which temporary agency use may lead to lower overall wage growth.

\footnotetext{
${ }^{1}$ See Katz and Krueger (1999) for a documentation of this phenomenon and some hypotheses about its causes.

${ }^{2}$ See, for example, discussions on wage setting processes in internal labor markets in Doeringer and Piore 1971 and Levine, et al. 2002, Chapter 2.
} 


\section{WHY EMPLOYERS USE AGENCY TEMPORARIES IN TIGHT LABOR MARKETS: A CONCEPTUAL FRAMEWORK}

We begin by providing a conceptual framework for organizing and interpreting the case study information presented in subsequent sections. We assume that employers use agency temporaries in lieu of other factor inputs, such as direct-hire temporaries or regular employees, to reduce costs. Such cost savings can occur through a variety of mechanisms and we offer several potential explanations for why companies used and, on average, increased their use of temporary agency workers in the very tight labor markets characterizing the U.S. economy in the 1990s.

One potential explanation is that companies often find it cost-effective to hire workers on explicitly temporary contract when the work is expected to be temporary or is of uncertain duration and companies have more such work when the economy is booming than when it is in recession.

Theoretically, there must be some difference between temporary and regular workers to explain employers' use of explicitly temporary contracts. To generate greater employer demand for temporary workers when an increase in workload is temporary or of uncertain duration, previous theoretical models (Abraham 1988, Kandel and Pearson 2001) have assumed that workers on temporary contract are less productive than regular workers but less costly to terminate. ${ }^{3}$ The amount of temporary work may increase during an expansion, as companies take on special projects that are intrinsically short-

term in nature. Moreover, during an expansion employers are more likely to experience an increase in

\footnotetext{
${ }^{3}$ These termination costs can take various forms. U.S. employees have some rights to advance notice in the event of a mass layoff, and many state courts have granted workers legal protection against unjust dismissal in specific circumstances (Autor 2003). Moreover, companies may adopt personnel policies providing implied commitments of job security to regular employees in order to reduce turnover and build firm-specific human capital among a core set of workers. Independent of any legal restrictions, breaking these implied commitments may have costs, including lower morale and productivity and higher turnover. The assumption that regular employees are more productive-or have some other cost advantage-is needed to generate an economy with both regular and temporary workers.
} 
their workload that, at least with some probability, is perceived as temporary. For instance, as employment increases during an expansionary period, employers may increase their relative use of temporary workers to buffer core workers, who are more expensive to lay off, against a possible downturn. This first explanation for why companies are more likely to use temporary workers when the economy is booming is akin to a scale effect: the greater quantity of temporary work will result in greater employer demand for all temporary workers: agency temporaries as well as temporary workers hired directly by companies. ${ }^{4}$

A second explanation is related to the fact that many companies use temporary agency workers to fill vacancies until permanent hires are made, in some cases, recruiting permanent workers from the ranks of the agency temporaries. The empirical importance of using agency temporaries to fill vacancies and to screen workers for permanent positions has been well established in recent surveys (Abraham 1990, Houseman 2001b, Kalleberg, Reynolds, and Marsden, 2003). Because agency temporaries are used for new hires and the accession rate moves procyclically, the share in temporary agency employment would also move procyclically. It is interesting to note that under this scenarios, the share in temporary employment would increase during an expansion even if the nature of the increased workload is not temporary.

Finally, companies may substitute agency temporaries for direct-hire temporaries or for directhire recruits during expansions if the cost of agency temporaries relative to that of direct-hire temporaries or recruits declines when labor markets tighten. Here, the share in temporary employment

\footnotetext{
${ }^{4}$ Abraham (1988) and Kandel and Pearson (2001) distinguish between temporary and permanent or regular workers, but not between types of temporary workers. The distinction between workers hired through third parties-like temporary agencies-and direct-hire temporaries is a critical component of the theory and empirical evidence presented below.
} 
would grow during an expansion not only because the accession rate was increasing but also because the share of new hires who were agency temporaries was increasing.

Regarding the last two explanations, there are various reasons why temporary agencies may enjoy a cost advantage in the recruitment and screening of temporary and permanent workers and why their cost advantage may increase when labor markets tighten. When labor markets are slack, it is relatively easy for companies to form in-house, on-call worker pools or to hire temporaries directly. When labor markets tighten, the supply of workers willing to accept temporary work or unpredictable hours shrinks at any given wage. Because temporary agencies pool jobs across companies, they can offer workers more steady employment, or for those who desire temporary work, agencies are better able to offer them employment when they want to work. Similarly, temporary agencies likely enjoy scale economies in recruiting and screening workers for permanent positions, especially in tight labor markets when companies have fewer unsolicited, qualified job applicants and receive fewer qualified applicants for any recruiting expenditure.

In addition, we argue that the use of temporary agency workers to fill temporary positions or to fill vacancies while companies recruit permanent workers is often advantageous to companies because they may discriminate between temporary agency and direct-hire workers in the compensation offered. However, the direction of the wage discrimination along with the precise mechanisms by which temporary agencies are able to recruit workers and companies are able to save on compensation costs will depend on the labor market. ${ }^{5}$ We outline two scenarios below.

\footnotetext{
${ }^{5}$ We use the term "wage discrimination" to denote the payment of unequal wages or compensation to agency temporary and permanent workers who are assigned to the same job.
} 


\section{- $\quad$ Agency temporaries receive higher wages than direct-hire employees.}

Suppose, for now, that the workers an employer hires for a particular position are homogeneous in quality. The market wage rate, $w$, facing individual employers depends upon the degree of labor market tightness, proxied by the unemployment rate, $\mu, \frac{\delta w}{\delta \mu}<0$. We assume that an employer's existing workforce faces some costs in switching jobs. ${ }^{6}$ Therefore, across some range, a decline in the unemployment rate will not force an employer to raise wages to prevent existing workers from quitting to take new jobs. Similarly, we assume that wage cuts cause serious morale and productivity problems and consequently an employer will not lower wages for existing employees when unemployment increases, at least across some range. With the standard assumption that workers within the firm receive the same wage (i.e., no wage discrimination), the marginal cost of a new hire at time $t$ is simply the wage paid to existing workers when the unemployment rate has been stable or rising since the last hire. However, if a firm wishes to hire additional labor, $L$, and labor markets have tightened since it last hired, the marginal cost is the higher

$$
w_{t}+\left(\frac{\delta w}{\delta \mu}\right)\left(\frac{\delta \mu}{\delta t}\right) L_{t}, \quad \frac{\delta \mu}{\delta t}<0
$$

wage it must offer the new worker, plus the pay raise it must offer existing workers:

A cost-minimizing employer would prefer to wage-discriminate, offering higher wages only to new workers. With wage discrimination, the marginal cost of hiring additional labor is simply the wage

\footnotetext{
${ }^{6}$ These adjustment costs could include information costs in finding out changes in wage rates or preferences for the status quo. In models with heterogeneous labor, they could include firm-specific human capital for which the worker receives some additional compensation.
} 
of the new hire. It is generally assumed that employers do not practice wage discrimination, even if existing workers face high costs of switching jobs, because such a two-tiered wage system would be seen as unfair by workers and result in serious morale and productivity problems. However, we argue any adverse morale and productivity effects are likely mitigated when new workers, who make more money than existing workers, are hired through a third party, such as a temporary help agency. These adverse morale and productivity effects might be lower if regular employees are less knowledgeable about temporary agency workers' wage levels than they are about other employees' wage levels. It may be more costly for employees to gain information about wage levels in other companies-in this case temporary agencies-than in their own company, particularly if the referring agency is not local. Additionally, employees may have fewer social contacts with agency workers than with other employees, and hence opportunities to exchange wage information, particularly if agency workers are on short-term assignment. Alternatively, because the client company does not directly set the wages of the temporary workers, employees may not fully blame their employers for the wage differentials.

Formally, suppose that the cost of hiring an additional worker and paying her more than existing workers is $K$ if the worker is hired directly, but only $k, k<K$, if the worker is hired through a third party. Then, if the firm chooses to practice wage discrimination, it will only do so through a third party, like a temporary agency, and it will only practice wage discrimination in new hiring if the additional payments to existing workers, $\left(\frac{\delta w}{\delta \mu}\right)\left(\frac{\delta \mu}{\delta t}\right) L$, exceed the marginal cost of wage discrimination, $k$. 
Thus, when unemployment is falling, and hence wages of new hires are rising, some employers may choose to practice wage discrimination through a temporary agency. ${ }^{7}$

The use of temporary agency workers may also make it possible for employers to discriminate in the composition of the compensation package offered in ways that would be illegal or impractical if all workers were employees. For instance, nondiscrimination clauses in the Employee Retirement Income Security Act (ERISA) and the Internal Revenue Service tax code make it difficult for employers to offer different benefits packages to different groups of full-time employees. ${ }^{8}$ Temporary help agencies, which typically offer much lower benefits levels than client firms, likely attract some workers who place a low value on company-provided benefits. For instance, workers with health insurance coverage from another family member may place little or no value on health insurance benefits offered by their employer. Therefore, if the cash component of compensation in temporary jobs is higher than the cash component in regular jobs, it is possible that temporary agency workers place a higher value on the compensation from the temporary agency than the compensation they would earn in a regular employment position, even if the total cost of providing that compensation package is the same or less. In these cases, the use of temporary help agencies allows efficient sorting of workers by compensation preference and potentially benefits workers and employers alike.

Thus far, the choice between regular and temporary workers has been posed as a one-time decision by employers seeking to increase their workforces. One might more realistically think of the

\footnotetext{
${ }^{7}$ Bellemore (1998) develops a similar model of wage discrimination to study wage differentials between agency and regular nurses. Our model differs from his in that it does not require that employers have monopsony power in labor markets; rather, in our model, employers face rising wages over time if labor markets tighten.

${ }^{8}$ ERISA and non-discrimination clauses in the IRS tax code are designed to ensure that highly compensated individuals are not the primary beneficiaries of fringe benefits that constitute in-kind, tax-free or tax-deferred income. See Houseman (2001a) for further discussion of these rules.
} 
process as a dynamic one in which firms temporarily use higher-priced temporary labor in order to buy additional time to fill permanent vacancies. Specifically, in a model in which workers have imperfect information about the distribution of potential wage offers, a firm's probability of filling a vacancy at any point in time would vary positively with the wage package and the unemployment rate. ${ }^{9}$ Employers may quickly recruit high-priced temporary agency labor to fill vacancies, buying time to recruit permanent workers at lower wages. ${ }^{10}$ Whether or not employers choose to utilize temporary agency workers for this purpose will depend on the price of temporary relative to permanent workers, the time it would take to recruit regular workers at lower wages, and the cost of leaving vacancies unfilled. In this dynamic context, the essential theoretical insight is the same as in the static model discussed above: it may be advantageous for employers to hire temporary workers in tight labor markets because they can discriminate in the wages they offer temporary and permanent workers and thereby avoid raising wages for existing workers.

- $\quad$ Agency temporaries may receive lower wages than direct-hire employees.

Consider now a labor market in which there are two types of workers: $L_{1}$ are "good" workers, who have good work histories and are certain to work out; $L_{2}$ are "risky" workers who have poor or no work histories, but, with probability $\rho$, will prove to be "good" workers, $0<\rho<1$. Wage levels for good workers are greater than or equal to those of risky workers, $w_{1} \geq w_{2}$. Risky workers who

${ }^{9}$ The assumption that vacancies and thus employment levels are a function of the wage rate has been used in a number of theoretical models. For a review of these models, see Card and Krueger (1995).

${ }^{10}$ Note that even if temporary workers are paid more, some workers may still prefer permanent positions. This is because temporary and permanent positions are not identical-the latter is associated with more job security and possibly more benefits. Thus, for some workers, the non-compensation aspects of a permanent job outweigh the lower compensation, or their personal valuation of the total compensation package may be higher for the permanent job. 
prove themselves to be good workers receive $w_{1}$ after a probationary period. Risky workers who prove to be "bad" workers quit or are fired, with a cost $f$ to the employer; $f$ captures any direct costs of dismissal as well as recruitment and screening costs associated with turnover. Expected output is assumed to be a simple linear function of the two potential labor inputs: $E[Q]=L_{1}+\rho L_{2}$

When hiring, cost-minimizing employers will select a good or a risky worker depending upon the cost per unit of output for each type.

$$
\begin{gathered}
w_{1 t}<\frac{\left[w_{2 t}+(1-\rho) f\right]}{\rho}, \quad \frac{\delta \mu}{\delta t} \geq 0 \\
w_{1 t}+\left(\frac{\delta w_{1}}{\delta \mu}\right)\left(\frac{\delta \mu}{\delta t}\right) L_{1 t}<\frac{\left[w_{2 t}+(1-\rho) f\right]}{\rho}, \quad \frac{\delta \mu}{\delta t}<0
\end{gathered}
$$

When the unemployment rate has been stable or growing, the marginal cost of hiring a good worker is just the wage paid to that worker. With $f$ and $\rho$ varying across firms, some employers may choose to hire risky workers during periods when the unemployment rate has been rising and labor markets are slack. When the unemployment rate has been falling, employers must raise wages to hire a good worker and so must also raise wages for existing employees, $L_{1}$. Consequently, for any given wage gap between good and risky workers, it is more attractive for employers to hire risky workers when labor markets have been tightening. ${ }^{11}$

\footnotetext{
${ }^{11}$ In this model, employers will find it more attractive to hire risky workers as labor markets tighten, unless the wage gap between risky and good workers narrows so much that it negates savings realized from the lower wages paid to existing workers. Although we do not discuss how $w_{1}$ and $w_{2}$ are set, we argue the wage gap, if anything, is likely to expand as labor markets tighten. In slack labor markets, there is involuntary unemployment
} 
Temporary help agencies potentially reduce the costs to employers of hiring risky workers in several ways. First, temporary agencies will raise $\rho$ the probability that a risky worker will work out on a particular job, if they are more efficient in matching workers to jobs. Second, hiring a risky worker through a temporary agency may lower $f$, the cost of a quit or dismissal. By lowering recruitment costs, temporary agencies lower the costs of replacing workers and hence of using workers with low $\rho$. Further, temporary workers, who are not employees of the client company, are probably less likely than direct-hire employees to sue over a dismissal. In support of this notion, Autor (2003) finds a strong empirical link between the decline of employment-at-will in state law and the growth of temporary agency employment. Additionally, managers often find it difficult to dismiss a worker who displays poor or mediocre performance. Arguably, managers are less likely to offer permanent employment to a poor or mediocre temporary agency worker than they are to fire a similar direct-hire employee. The benefit of using temporary agencies to screen workers for permanent positions, then, is a more productive workforce.

Finally, a company may be unwilling to give more risky workers a chance at employment at its existing entry-level wages. While in theory it could offer lower wages to new hires, offering new entrants substantially lower wages than existing workers may cause morale and productivity problems among new entrants. Moreover, the company may be legally unable to discriminate against new workers in the benefits package it offers them. Above, we argued that a company may use temporary

among both labor types; $w_{1}$ and $w_{2}$ become more compressed in slack labor markets, perhaps because of minimum wages or other social safety nets. Thus, employers are more likely to prefer good workers over risky workers in slack conditions. Even in tight labor markets, low-skilled disadvantaged workers experience substantial unemployment-again perhaps because of social safety nets-mitigating upward wage pressure on $w_{2}$, and, we argue, widening the gap between risky workers and good workers, at least in low-wage labor markets 
agency workers in order to offer higher wages to new entrants. However, a company may also use temporary agency workers to facilitate offering new entrants lower overall compensation.

In this model, the share in temporary employment will increase during expansions for two reasons. First, companies use agencies to screen risky workers and the rate of new hires is procyclical. Second, the cost of hiring good workers relative to risky workers increases as labor markets tighten, and so companies are more likely to choose to hire risky workers through temporary agencies than hire good workers directly.

In this simple model, companies face perfectly elastic supply of good and risky workers when making new hires, and choose to hire all of one type at any point in time. As discussed above, however, when workers face search and information costs, an employer's probability of filling a vacancy at any point in time varies positively with the wage offered. Under this scenario, an employer may follow a mixed strategy, hiring some good workers at relatively low wages directly, and filling remaining vacancies with risky agency temporaries.

\section{Implications for Wage Growth}

The preceding discussion suggests several avenues by which temporary agencies may relieve pressure on companies to raise wages in tight labor markets. Temporary help agencies may enjoy a comparative advantage in recruiting and placing workers, especially in tight labor markets. Thus, the substitution of agency temporaries for direct-hire temporaries and recruits may reduce pressure on companies to raise wages by virtue of this better matching. If companies utilize agencies simply because they have a comparative advantage in recruitment and screening, we would not expect to observe any systematic differences in the wages of temporary and regular workers in the same job. 
However, evidence that agency temporaries earn systematically higher or lower wages than comparable regular workers would suggest wage discrimination and a different or additional mechanism by which temporary agency use results in lower aggregate wage growth and unemployment. In some cases, temporary help agencies may be able to recruit qualified candidates by paying them more than companies pay regular workers. Here companies are effectively able to practice wage discrimination, paying higher wages to new entrants than to longer tenure employees. ${ }^{12}$ Companies may also utilize higher priced agency help to buy themselves time to recruit regular workers. This practice is most likely to occur when the qualifications for a position are well-defined and easily observed or when the potential costs to an employer of trying out a risky worker are great. We argue that this practice is most likely to be associated with high-skilled labor markets, where workers must meet clear educational or certification requirements to perform jobs and where the costs of having an unqualified person staff a position are high.

In other cases, temporary help agencies may make the use of less qualified, more risky workers acceptable to companies by lowering their wages or lowering the costs of firing and replacing them. In this case, temporary help agencies effectively expand the supply of labor and mitigate the need for companies to raise wages to attract more qualified applicants. This practice is most likely to occur when applicants' qualifications for a job are difficult to observe and where the costs of trying out risky workers are low-or made low by the temporary agency. We argue that this practice is most likely to be associated with low-skilled labor markets. In these markets, although most individuals are capable

\footnotetext{
12 The hypothesis that temporary agencies result in more efficient matching is the one primarily espoused in Katz and Krueger (1999). However, they also raised the possibility that companies would wage discriminate in favor of temporary agency workers.
} 
of performing the required tasks with minimal training, employers complain that many lack so-called "soft skills", such as honesty, punctuality, and the ability to get along with co-workers. These soft-skills are difficult for employers to observe $a$ priori, especially among applicants who lack a good work history.

\section{CASE STUDY METHODOLOGY}

The evidence we present is based on extensive interviews conducted in six hospitals and five auto suppliers in 1999 and 2000. We chose these two industries to represent a service and manufacturing industry, respectively, that play prominent roles in the U.S. economy and that utilize large numbers of workers in nonstandard arrangements, including agency temporaries. ${ }^{13}$ However, we had little or no knowledge about a specific organization's use of temporary agency workers prior to selecting it for case study. Although we cannot claim that this small sample is fully representative of organizations in the hospital and auto supply sectors, we sought to represent a variety of organizations within each industry. Our hospitals came from two distinct geographical regions: three were in Michigan and three were in North Carolina. The utilization of temporary agencies may be affected by an organization's size, for instance, with smaller organizations having a greater incentive to take advantage of scale economies in recruiting that temporary agencies may offer. The hospitals in our sample varied in size from a small Michigan hospital with 450 employees to a large North Carolina

\footnotetext{
${ }^{13}$ We also studied a representative public sector industry, primary and secondary public schools. We do not include public schools in this paper because relatively little use is made of agency temporaries in this industry. Based on case studies in all three industries, we discuss the effects of a broader set of nonstandard work arrangements on low-skilled workers in Erickcek, Houseman, and Kalleberg (forthcoming).
} 
hospital with 6,000 employees. An organization's use of agency temporaries may also depend on the presence of a union; one hospital in our sample was unionized. ${ }^{14}$

Although all of the auto suppliers represented in our case studies were from the Midwest, the suppliers varied across other important dimensions: size, presence of a union, and ownership structure. The auto supply establishments employed between 430 and 2,100 employees. Two of the plants were unionized. Two were locally owned facilities, one was a branch plant of a larger U.S. company, and two were subsidiaries of foreign-owned companies. Plants that are part of a larger corporation, particularly a foreign-owned company, may have different personnel practices that affect temporary agency use.

Within hospitals, we interviewed the human resources director and managers in key functional areas: nursing, clerical and administrative support, laboratory, food services and housekeeping, and clinical specialties (e.g., radiology, physical therapy). In two hospitals, we conducted focus groups of permanent and temporary agency nurses. We also interviewed managers at several temporary agencies that supplied nurses and medical assistants to the hospitals we studied.

In the auto supply companies, we focused exclusively on production workers, who account for most of employment in these organizations. We interviewed the human resources director and production managers in each plant. At one facility, we were able to conduct two focus groups with workers: one with regular full-time production workers and the other with agency temporaries. We

\footnotetext{
${ }^{14}$ Corporate structure could also impact incentives to minimize labor costs and utilize agency staff. None of the hospitals in our sample were private for-profit. Three were public and three private, not-for-profit.
} 
also interviewed the on-site representative of the temporary agency at the three facilities having such a representative.

We developed a structured set of questions for each type of interview conducted in the two industries. This ensured that a core set of questions was asked in each case study. However, we asked follow-up questions to interviewees' responses to these core questions, which allowed us to clarify their answers and gather more information about particularly interesting practices. We tape recorded and transcribed all of our interviews.

Finally, we collected data from each participating organization on employment levels, hours worked, wages, and benefits of employees for each occupation. Where available, we also collected information on the extent of an organization's use of temporary workers by occupation, the billed rate paid to the temporary agency, and the actual wage paid to the temporary worker. ${ }^{15}$

\section{HOSPITALS' USE OF AGENCY TEMPORARIES IN TIGHT LABOR MARKETS}

Pressures on hospitals to curb costs grew during the 1990s, due primarily to declining reimbursement from the federal government and insurance companies and the growth of managed care organizations. Against the backdrop of pressures to curb costs, hospitals faced especially tight labor markets in nursing and other specialized clinical staff (Anderson and Wootton 1991; Buerhaus, Staiger, and Auerbach 2000).

Table 1 presents quantitative information on temporary agency use by occupation for the five hospitals maintaining such records. Hospitals used temporary agency workers for both high- and low-

\footnotetext{
${ }^{15}$ A data appendix describing these data and the construction of variables reported in this paper is available from the first author on request.
} 
skilled occupations. The extent to which agency temporaries were used for various occupations differed across hospitals. Registered nurses represent the largest single occupation in a hospital, and temporary agency RNs were used by all but one of the hospitals we studied. Although agency RNs generally accounted for a relatively small share of total RN hours worked in each hospital (column 1, Table 1), they accounted for a sizable share of the hospitals' total temporary agency expenditures (column 3, Table 1). Hospitals also used temporary agency workers in other high-skilled clinical occupations, such as radiographers, cardiovascular technologists, respiratory therapists, and technicians to operate CT, MRI, and ultrasound equipment.

In addition, hospitals used temporary help agencies to obtain workers for relatively low-skilled clinical occupations such as nursing assistants and patient sitters. Workers in the latter occupation watch extremely ill or confused patients and call for assistance, when necessary. In all of the hospitals except M2, agency temporaries accounted for between 3 and 7 percent of total hours worked by these low-skilled nursing and medical assistants.

Finally, hospitals used temporary agency workers in low-skilled support functions, particularly clerical. Agency clerical workers in "unit administrative support" accounted for a sizable share (7 to 11 percent) of total hours worked in this occupation in three of the hospitals studied. Three hospitals reported using agency temporaries in food services and housekeeping functions. Though data on agency use in food services and housekeeping are available for just one hospital, figures for this hospital suggest extensive reliance on agency temporaries to staff these positions. ${ }^{16}$

\footnotetext{
${ }^{16}$ One hospital kept no central records of its use of temporary agencies and the other hospital kept no central records of agency use in housekeeping and food services, perhaps because the management of these functional areas was outsourced.
} 


\section{Why Hospitals Use Temporary Agency Employees in High-Skilled Clinical Positions}

Our interviews with managers revealed several situations in which they used agency temporaries in nursing and non-nursing specialties. Variability in workload is one reason why hospitals used temporary help agencies for more highly skilled occupations, such as nurses. Hospitals are required by state codes to maintain minimum nurse/patient ratios, for example, yet hospital occupancy rates fluctuate widely. Hence, using temporary help agencies enabled hospitals to add nurses as needed to satisfy peaks in demand, and avoid overstaffing during other times. A second and related reason for using temporary staffing was to cover for absences of regular employees, who were sick, on vacation, or on extended leave.

A third reason for using temporary help agencies, cited by managers in all of the hospitals in our study, was to temporarily fill a vacant position. Managers universally reported a shortage of nurses and workers in some non-nursing specialties, which led to a large number of unfilled vacancies on their staff and a greater demand for agency temporaries to fill these vacancies while they recruited permanent staff. Some hospital managers reported that they explicitly recruited permanent staff from the pool of agency temporaries, while others reported rarely doing so.

Interestingly, although we predicted a negative correlation between firm size and temporary agency use owing to economies-of-scale enjoyed by the latter, the smallest hospital in our study (M2) was the only one to not use agency help in high-skilled clinical positions. Like the other hospitals, it reported difficulty in filling these positions, but could not get reliable service from agencies, whom, it claimed, chose to focus on larger, higher-volume clients. 
Although the other five hospitals all used temporary agency personnel in high-skilled clinical positions to handle an increase in workload, fill in for staff absences, or fill vacancies in permanent positions, they all viewed the use of temporary agency workers in these situations as a measure of last resort. They preferred to use in-house on-call staff or to fill vacancies with permanent workers. Hospital managers essentially cited two reasons for preferring in-house staff over agency temporaries: competency and cost. With respect to the first, most nurses and hospital administrators we interviewed were happy with the quality of the temporary agency staff, especially with "traveler" nurses, who typically work in highly specialized areas, such as critical care, and who are placed in hospitals around the country by national level agencies for relatively long assignments (one to three months or more). However, some hospital administrators complained about the uneven quality of nurses placed by local agencies. Some also felt that agency nurses were less productive than regular staff nurses, but primarily because of their lack of familiarity with the hospital's organization.

Concern over the high cost of high-skilled temporary agency employees (such as nurses) compared to in-house staff was echoed in our interviews with all of the hospitals. Hospital administrators unanimously believed that the bill rate charged by temp agencies for nurses and nonnurse professionals exceeded the wage and nonwage labor costs associated with comparable in-house staff. The information we were able to obtain on the costs of using in-house versus temporary agency staff in high-skilled occupations supports these assertions. Table 2 shows the average total cost of fulltime, in-house staff and the bill rate charged by temporary help agencies, by occupation, for five of the hospitals in our study. In all cases where hospitals used temporary help agencies to fill $\mathrm{RN}$ or other 
highly skilled clinical positions, the hourly bill rate for the temporary agency workers exceeded the average total hourly cost of full-time workers. In most cases the bill rate was substantially higher.

So why did hospitals use temporary agency rather than in-house staff if temporary agency workers were possibly less productive and cost more? The answer given by the hospitals was a national "labor shortage" in nursing and some non-nursing professional occupations. Most hospitals indicated that they tried or were trying to build up their in-house on-call pools and were trying to recruit permanent staff. However, they were unable to recruit sufficient on-call and permanent full-time employees to meet their staffing needs, by implication, at the wages they were offering.

How were temporary help agencies able to recruit employees when the hospitals could not? Evidence from our interviews with hospital and temporary agency administrators and nurses in both Michigan and North Carolina suggests that temporary help agencies recruited nurses and other hospital professionals, quite simply, by paying them more than hospitals did. In the words of a hospital administrator in Michigan, "One reason why temp agencies are able to get nurses and we're not is that they are paying them outrageous dollars that we won't pay."

That the hourly wage of temporary agency nurses and other temporary health care professionals was higher than that of hospital employees seemed to be a fact well-known to hospital administrators and employees. Traveler nurses and other health care professionals who were placed by a national agency in a hospital for relatively long periods of time earned particularly high salaries. One North Carolina hospital was using traveler temporary help agencies to fill two out of four radiation therapist positions; in one case the traveler had been with the hospital almost a year. When asked why 
the temporary agency could attract employees when her hospital could not, a supervisor from this hospital replied,

The temp agencies are paying them money, they are paying for their rent, they are paying their food, they're paying their car, they're paying their travel. They earn a lot more . . . and I can't compete with that. The gentleman who has been with us for 11 months now, I tried to offer him a position 9 months ago and I could not compete.

Other hospital administrators also noted the extremely high costs associated with traveler nurses and the fact that these individuals, while highly trained, were earning substantially more than in-house staff.

It appears that even some local agencies, which tend to supply less highly specialized health care professionals than do the traveler agencies, paid wages that exceeded the value of wages and benefits received by hospital personnel in comparable positions. One local temporary help agency in Michigan reported paying \$29 to \$30 per hour to its RNs, which compared to about \$17 per hour that the typical RN received in the hospitals the agency serviced. Even though the temporary agency did not pay benefits to its nurses, the huge wage premium — on the order of 70 percent—exceeded the value of benefits a worker would have received from a hospital. When asked why the temporary agency paid such huge wage differentials, the manager at the temporary agency replied,

Because that's what the market bears. It's very simple. If you look in the paper and read the ads [from other temporary agencies], they are just one after the other, $\$ 2,000$ bonus, $\$ 30$ an hour. I mean, we just couldn't recruit if we didn't pay that.

She also insisted that temporary help agencies had been paying their nurses large premiums over what hospitals paid for years. According to this same temporary agency manager, the temporary agencies attracted many nurses who had benefits from other sources and thus did not need benefits from their employer. Thus, even if the wage premium paid by the temporary agency does not exceed the value of 
the benefits offered by hospitals, it is likely to be an attractive employer to those who place a low value on company-provided benefits. ${ }^{17}$

Of course, the higher cost of the temporary agency nurse is passed on to the hospital through the agency's bill rate. Does a strategy of hiring temporary agency workers at such high cost make sense? In the case of nurses and other professional hospital staff, the use of temporary help agencies effectively becomes a vehicle for hospitals to pay higher wages to quickly fill vacancies without raising the compensation of existing workers. Moreover, hospitals continue to try to hire permanent and inhouse on-call staff, thereby using agency temporaries to buy time to recruit employees at the hospital's lower wage levels. ${ }^{18}$ All other things equal, such wage discrimination likely lowers an organization's overall labor costs. $^{19}$

Could hospitals practice such discrimination themselves without going through an intermediary? Our evidence suggests that temporary help agencies attract many workers who place a high value on wages relative to benefits. ERISA and nondiscrimination clauses in the IRS tax code would likely make it legally difficult for hospitals to exclude certain groups from benefits. Moreover, as argued above, while hospitals legally could offer new permanent employees or direct-hire temporaries higher wages than existing employees, the adverse impacts of such a wage policy on employee morale and productivity would likely cancel out any savings on hourly wage costs.

\footnotetext{
${ }^{17}$ Supporting this argument, Bellemore (1998) presents evidence that temporary agency nurses value certain benefits less than regular nurses.

${ }^{18}$ Certainly, temporary agency and in-house staff positions are not homogeneous, with the latter offering more regular employment, and possibly, in the case of regular workers, better benefits. Job matching models, cited above, would predict that the amount of time it takes for a hospital to fill a job vacancy would be inversely related to the wage level and the size of the wage gap between in-house and temporary agency positions.

${ }^{19}$ Formally, from equation (1) above, the marginal cost of a new hire is $w_{t}$ with wage discrimination, which is less than $w_{t}+\left(\frac{\delta w}{\delta \mu}\right)\left(\frac{\delta \mu}{\delta t}\right) L_{t}$ without wage discrimination.
} 
Do hospitals avoid this adverse effect on morale by hiring through a third party? Our evidence on this issue from interviews with hospital administrators, nurses, and temporary agency managers is mixed. For instance, one hospital in North Carolina experienced serious morale problems among its nursing staff as a result of the wage differentials. In response to a question about whether the wage differential between temporary and regular nurses causes problems, an administrator in this hospital replied,

Yes, big time. It becomes a real irritant — a tremendous irritant for our nurses. They're saying, 'Pay us the money, you are paying all this money out to a traveler, why aren't you paying us and giving us retention bonuses and getting us to stay? ... And if the hospital can find money for travelers, they could find money for me.'

In other hospitals, resentment among regular nurses over the higher wages that temporaries made was mitigated by the fact that temporary nurses eased pressures on them to work overtime and unpopular shifts. As expressed by a hospital administrator in Michigan,

You know, there's always resentment when people are working side by side with someone they know is making more money than them for the same job. But by the same token, if the temps weren't here, their vacations would be canceled ... they are doing the job that you didn't want to do. Remember, you could have had these hours and you didn't want them, because they are always offered to the staff first. If you continue to do that kind of education, then I think there is less resentment...

An administrator in another North Carolina hospital reported few morale problems in using temporary nurses, in part because the regular nurses were "thrilled to have the help." This administrator also suggested that regular nurses might not be fully informed about the wage differentials: "I don't know if they [temp nurses] are trained or what, but they've got enough sense not to sit around and brag about how much money they make." In interviews with other hospitals, we found that although 
hospital administrators and regular nurses generally knew that temporary nurses earned more money than regular staff, they often were uncertain as to how much more.

Thus, while hospitals cannot fully avoid morale problems associated with wage differentials, using a third-party intermediary to pay higher wages to new workers likely mitigates the problem. Regular staff may not blame the hospital for the wage differential, since the hospital does not directly determine the wages of temporaries. Moreover, regular staff members are likely to be less informed about the wages of temporaries than they are about other employees, and hence not focus on this issue.

In summary, we must emphasize that in no case did hospital administrators actually say that they used temporary agencies to avoid raising wages of regular staff. Instead, what they said was that they could not fill vacancies fast enough and that they "had" to use temporary staff to fill in while they tried to recruit permanent employees or on-call staff. Their alternative was to raise wages to attract nurses and other professional staff more quickly, an alternative that hospital administrators generally did not view as viable, perhaps given the pressures they faced from HMOs and Medicare reform to lower costs. Given that hospital administrators tended to view the wages they offered nurses and other professional staff as relatively fixed, they indeed were constrained in their ability to hire new staff. They were able to relieve these constraints by using temporary staff, whose wages were more responsive to market forces. What we argue is that by using temporary agencies to fill nursing and other skilled positions, hospitals were effectively introducing a two-tiered compensation system; from theory developed above, this was likely a cost-effective strategy.

This finding from our case studies in hospitals is consistent with evidence of wage differentials between temporary agency and regular nurses reported in Bellemore (1998). It also offers one 
explanation for recent stagnant wage growth in nursing. Both nominal and real wages of RNs rose slowly in the 1990s compared to the 1980s. From the National Sample Survey of Registered Nurses, average nominal earnings of full-time registered nurses rose at a rate of 6.5 percent from 1980 to 1992, while they rose at a rate of just 2.7 percent from 1992 to 2000. Moreover, while real earnings for fulltime RNs increased at a rate of 2.4 percent from 1980 to 1992 , they rose at a rate of just 0.1 percent from 1992 to 2000 . Wage growth was especially low among hospital RNs, and this low wage growth cannot be attributed to changes in skill mix (Schumacher 2001). The stagnant real wage growth for RNs during the 1990s is particularly surprising given reports of a severe shortage of RNs in many areas of the country. Our case study evidence suggests that use of temporary agency nurses during the 1990s is one explanation for the stagnant real wage growth. Although temporary agency RNs in the hospitals we studied comprised a small share of the $\mathrm{RN}$ workforce, they arguably had an important effect on wage growth by relieving pressures on these hospitals to raise wages for their employees. ${ }^{20}$

\section{Why Hospitals Use Temporary Help Agencies in Low-Skilled Occupations}

Besides nurses and medical specialists, the hospitals in our study made extensive use of agency temporaries in medical assistant and clerical positions and sometimes in food service and housekeeping positions (Table 1). Hospitals reported hiring agency temporaries in low-skilled positions both to meet temporary staffing needs and to fill vacancies while they recruited permanent hires. With respect to the first, a hospital's need for patient sitters, who watch extremely ill or confused patients, is unpredictable and varies from day to day. The hospitals in our study all staffed patient sitters entirely through

\footnotetext{
${ }^{20}$ Schumacher (2001) suggests the growth of HMOs played some role in the low wage growth among RNs . By imposing greater cost constraints on hospitals, HMOs may have contributed to the lower wage growth and the development of shortages among high-skilled hospital staff, spurring the use of agency temporaries.
} 
temporary agencies. Similarly, two of the three hospitals reporting agency help in clerical positions were staffing one-time special projects. It was unclear from our interviews why hospitals chose to use temporary agencies in these positions in lieu of forming their own on-call pools or hiring temporary workers directly. However, hospitals reported difficulty maintaining on-call pools for nurses in the economic environment prevailing at the time, and it is likely that they would have had more difficulty than temporary help agencies-which pool jobs across companies and enjoy scale economies in recruiting and screening-in attracting a temporary workforce.

As with nurses and other high-skilled clinical staff, managers also used agency temporaries to fill vacancies in low-skilled jobs while they tried to recruit permanent staff. As hospitals came under intense pressure to reduce costs, wages in these low-skilled positions became uncompetitive with wages for low-skilled workers in competing sectors. In the words of one manager, "We had a problem attracting recruits. Frankly, McDonald's and Burger King were paying what we were and [workers there] don't have to go through the stress or the hassle or the hours or the customer service that they are required to perform here." The utilization of agency temporaries became a way of quickly staffing positions while managers continued to try to recruit permanent workers at relatively low wages.

How were temporary help agencies able to recruit workers in low-skilled functions when the hospitals could not? In a few cases, hospital managers or temporary agencies reported that, as with agency nurses, temporaries in low-skilled positions received higher wages than permanent staff in comparable positions. More typically, however, temporary staff in low-skilled positions reportedly earned about the same hourly wage as entry-level regular staff. Because regular staff usually received some fringe benefits, while agency temporaries did not, total compensation of agency temporaries 
would be lower in cases where hourly wages were the same. Although temporary agencies may have been better able than hospitals to recruit labor at any given wage rate, universal complaints from hospital managers about agency referrals in certain low-skilled occupations suggests that for any given wage rate, agency temporaries were, on average, of lower quality than regular staff. ${ }^{21}$

The data we collected on the relative costs of regular workers and agency temporaries in hospitals are generally consistent with information reported in interviews. Comparison of the total hourly cost of full-time workers and the hourly billed rate for temporary workers is quite different for low-skilled workers than for RNs and other high-skilled clinical workers (Table 2). Although the billed hourly rate for agency temporaries was generally higher than the total hourly cost of regular workers in low-skilled clinical positions, the differential was considerably less than that found in high-skilled clinical positions. ${ }^{22}$ Moreover, the billed hourly rate for agency workers in clerical, food service, and housekeeping positions was generally lower than the total hourly cost of regular full-time workers in these positions. Data for this last set of occupations, in particular, are consistent with the hypothesis that temporary help agencies effectively expanded the supply of workers for low-skilled positions by lowering the cost to clients of utilizing lower quality or more risky workers.

\footnotetext{
${ }^{21}$ There were limits, however, to agencies' ability to attract low-skilled workers at very low wage levels. One hospital reported that both it and local temporary help agencies were unable to recruit any housekeepers at the hospital's desired wage: $\$ 7$ per hour. In this case the hospital offered a wage below the going rate for the lowest skilled, riskiest workers.

${ }^{22}$ The higher cost of agency temporaries relative to in-house staff in low-skilled clinical positions in three of the hospitals may be related to the heavy use of patient sitters, who have no counterparts in hospitals. Although these positions require little in the way of hard skills, patient sitters work with the most vulnerable population in the hospital and so require especially careful screening. Our data do not reveal whether the relatively high cost of agency temporaries in these positions reflected workers' wages workers or agency overhead.
} 


\section{AUTO SUPPLIERS' USE OF AGENCY TEMPORARIES IN TIGHT LABOR MARKETS}

Like hospitals, auto suppliers have faced considerable pressure to lower labor costs. Although the auto industry experienced record sales in the late 1990s and 2000, these volumes were reached with generous incentive packages that depressed profits. To increase revenues, auto assemblers pressed their suppliers to lower their costs. At the same time that they were under pressure to reduce costs, first-tier auto suppliers faced tight labor markets and had difficulty recruiting and retaining workers. Based on our case study evidence, we argue that auto suppliers used agency temporaries to help lower labor costs and to screen workers for permanent jobs.

Table 3 summarizes some of the characteristics of the auto supply plants in our study and the extent to which temporary agency workers were used in production. Two of the plants were unionized. In one of the these, the union contract prohibited the use of temporary agency workers, while in the other, the union contract strictly limited their use. Temporary agency workers were used regularly in production in the three nonunion plants. In two of these plants, agency temporaries comprised over 20 percent of production employment at the time of our interviews.

Most of the entry-level production positions in these plants were low to semiskilled, requiring one to three days of informal on-the-job training. At the time of our interviews, production workers had been working long hours for the past several years, and the plants had been producing at or above their designed plant capacity. The unionized plants had exhausted their "call back" lists of laid-off union workers. Turnover and absentee rates had been on the rise. All of the human resources directors reported difficulty recruiting and retaining good workers in the strong economic environment. 
The human resources directors and plant managers we interviewed listed several situations in which they used temporary agency workers. The two most common were to accommodate temporary increases in workload and to screen workers for permanent positions. One company also used temporary workers to buffer regular workers in the event of a recession.

\section{Buffering Core Workers}

Reflecting the labor practices of its foreign, parent company, Company $\mathrm{C}$ was strongly committed to not laying off any permanent employees. According to the human resources director at this plant, this was the original rationale for using agency temporaries. They believed that they needed to maintain about 10 percent of the production workforce in temporary positions to avoid laying off employees in an economic downturn. At the time of our interviews, the fraction of their production workforce coming from temporary help agencies was more than double their 10 percent target, indicating that other factors were also important in determining their use of agency help.

\section{Accommodating Increases in Workload}

Three of the companies used agency temporaries to meet sudden increases in production (A, B, and E, Table 3). Why did these companies choose to use agency temporaries rather than hire temporary workers directly, as was done by the unionized plant whose union contract prohibited the use of agency temporaries under any circumstances? In fact, traditionally these companies had hired on-call workers to meet such short-term needs. However, given the extremely tight labor markets and the fact that everyone on their call-back lists desiring employment had long since found it, human resources directors had substituted agency temporaries for on-call workers. 
Above, we outlined several reasons why companies might find it more attractive to use agency temporaries in lieu of direct-hire temporaries in tight labor markets. Because agencies pool job orders across firms, they may offer more steady employment or better match the hours a worker desires than a single firm could offer to workers in an in-house on-call pool. This gives temporary agencies a comparative advantage in recruiting workers for temporary assignments, especially in tight labor markets. In addition, when labor markets are slack, companies simply call workers off a layoff list. When labor markets are tight, companies need to spend resources recruiting and screening workers, and temp agencies, which enjoy economies-of-scale, may be able recruit and screen more quickly and cheaply. Along these lines, some companies in our study felt that given tight labor markets and the size of their human resources departments, they would be unable to recruit and screen workers quickly enough to meet sudden, large production increases. ${ }^{23}$ Finally, in tight labor markets, companies are under pressure to raise wages to attract temporary as well as permanent new hires. As argued below, the use of agency temporaries relieved pressure on companies to raise wages by facilitating the use of riskier workers.

\section{Screening Workers for Permanent Positions}

In all the firms we interviewed, agency temporaries assigned to limited production runs could apply for permanent positions on other production lines when their temporary assignments were complete. Moreover, all of the nonunion auto plants in our study explicitly used temporary agencies to screen workers for permanent positions. In two of these plants (B and C), new production workers

\footnotetext{
${ }^{23}$ As with hospitals, however, there was no correlation between agency use and establishment size, as would be predicted by an economies-of-scale argument. The absence of such a correlation in such a relatively small and homogenous sample does not necessarily imply economies-of-scale are unimportant, however.
} 
were being recruited exclusively through temporary help agencies. The other plant, A, recruited through a combination of direct hires and temporary agencies. Specifically, this company hired applicants with good work histories in manufacturing directly; more "risky" applicants were told they must go through a temporary agency to gain employment at the plant.

There was wide variation across plants in the length of time it took for a temporary worker to be hired as a permanent employee. In the union plant, temporary agency workers had to be either dismissed or hired on a permanent basis after 30 days. At the other extreme, it was common for agency temporaries to wait for a year before being offered a permanent job at Company $\mathrm{C}$.

Production supervisors spoke in unison regarding the benefits of screening potential workers through temporary employment agencies to lower their hiring risks. In tight labor conditions, many entry-level workers have criminal records, a spotty work history, and little or no experience in a manufacturing setting. In addition, the work activity at several of these facilities required teamwork and good communication skills. It was important for production supervisors to select workers that could "fit" into their production teams. As put by one supervisor,

I have the opportunity to observe this person over a period of time. I don't have just a half-hour snapshot to go by as in an interview. I can get to know the person, get to know their background a little bit, get to know what their behaviors are, what motivates them, what possible problem areas I might have with the individual.

The key question is why did these companies prefer to screen workers at an arm's length, through a temporary help agency, rather than hire workers directly for a probationary period, as had been done traditionally? We explored this issue in detail in our interviews. One hypothesis is that companies believe that they are less likely to be sued by dismissed workers if the workers are the 
employees of a temporary help agency (Autor 2003). None of the managers interviewed in our case studies, however, felt that concern over lawsuits affected their companies' decisions to use temporary agency workers.

Another hypothesis is that managers find it difficult to fire workers on probation. By using temporary agencies, managers may pass the unpleasant task of firing workers who display poor or mediocre performance on to the temporary help agency or, at the end of a temporary worker's contract, choose not to hire that worker on a permanent basis. One manager interviewed in our study indicated that this was a substantial advantage of screening workers through temporary help agencies:

There's a benefit [in using temp agency or contract workers] in the fact that it's a little bit easier to dismiss a contract employee ... For whatever reason they're not working out, the fit's not right, they're not making number, or their attendance is poor, I can call [the agency representative] and say, 'End their assignment.' You can give them reasons why, you don't really have to give them reasons why ... I mean, people in general, they hate to end people's jobs. I mean, that's not a pleasant thing to do ... [For workers hired directly on probation] you can still end their employment, but it's not a very frequent thing that happens ... it's like, okay, now I have to face the person and say you didn't work out.

In this more subtle way, the use of agency temporaries may lower the costs of firing workers and result in a more productive workforce.

A third hypothesis for why companies screen through temporary help agencies is to lower the wages of workers during their probationary period. As outlined above, in tight labor markets companies have more difficulty recruiting qualified workers at any given wage rate. Companies could attract more qualified applicants by raising their wage rates, but would likely need to raise the wage for existing as well as new workers. ${ }^{24}$ Alternatively, they could lower their standards and hire less qualified

\footnotetext{
${ }^{24}$ Indeed, one auto supplier reported briefly adopting this strategy of raising wages and trying to recruit experienced workers away from other employers, but abandoned it in favor of using agency temporaries.
} 
workers, offering them lower wages and fewer benefits. However, companies may be constrained in lowering compensation by internal wage scales or benefits regulations.

The cost data we collected from the auto suppliers are consistent with the hypothesis that companies screen new hires through agencies in part to lower wage costs during the probationary period. Table 4 reports data on the hourly wage made by temporaries, the billed hourly rate charged by the temporary help agency, the starting wage offered to permanent workers, and the total hourly wage cost for permanent workers, as available, in the five plants studied. Although the hourly wage of temporary agency and regular workers was the same, by contract, in the union plant, the hourly wage of temporary workers was lower than the starting wage of permanent workers in all of the nonunion plants.

Moreover, for all four of the plants using agency temporaries, the temporary agency bill rate was lower than the total hourly cost of a permanent hire. ${ }^{25}$ Three of the four companies using agency temporaries specifically acknowledged the cost savings in the interviews. In Company $\mathrm{C}$, the cost savings were particularly striking. According to the company's accounting department, a fivepercentage-point reduction in the share of temporary agency workers would increase labor costs by $\$ 1$ million over the course of a year. At the two unionized companies, the unions opposed the use of agency temporaries on the grounds that the company would circumvent union wages and benefits by

\footnotetext{
${ }^{25}$ We compare the agency bill rate with the total hourly labor cost, including benefits, of regular workers. Workers hired directly by the company typically did not receive benefits provided voluntarily by companies (e.g., health insurance, pension, life insurance) during their probationary period. Counting only mandatory benefit costs (e.g., social security contributions, unemployment insurance, workers' compensation), the hourly wage cost of new hires was still greater than the hourly bill rate of temporaries for the three nonunion companies. Moreover, when temporaries were hired, they were put on probation. Thus, hiring workers through a temporary agency became a way of extending the period without these benefits.
} 
using cheaper temporary help. The numbers from our case studies support this concern. Human resources directors at both unionized companies indicated that they would like to use or increase their use of agency temporaries, but were constrained by their union contract.

In sum, the use of temporary help agencies in low-skilled auto supply positions-as in many lowskilled hospital functions-appeared to reduce pressures on companies to raise wages in tight labor markets by lowering the cost of using more risky workers, thereby effectively expanding the supply of potential labor to companies. This sharply contrasts with the situation for high-skilled clinical occupations in hospitals, where agency temporaries earned considerably more than their hospital counterparts and billed agency rates were substantially higher than the total hourly costs of in-house staff. Thus, one consequence of using agency temporaries-reduced pressure to raise wages for existing staff-was the same in both the high-skilled and low-skilled scenarios, but the path to this outcome was quite different.

\section{Morale and Productivity Issues}

The fact that the hourly costs of agency temporaries in low-skilled production positions were less than those of direct hires does not necessarily imply that it was cost-effective for companies to use agency temporaries. Agency temporaries might have been less productive than those recruited directly by the company if the temporary help agency attracted a lower quality worker than the company could have itself attracted or if being a temporary worker lowered a worker's morale, perhaps because of the lower compensation.

However, the use of temporary agencies in auto supply did not seem to be a cause of the poor quality of applicants, but rather a response to the shortage of qualified applicants at the wages 
companies were offering. For instance, Company A hired good applicants directly, but referred applicants it considered high risk to the temporary agency, which then supplied these workers to the company under contract. Managers at all of the auto suppliers expressed alarm at the decline in the quality of the applicants for production jobs, and they attributed this problem to the tight labor market.

Concern that temporary workers were less committed to the organization and therefore were less productive or more likely to quit than direct hires was limited at three of the four auto supply companies using agency temporaries. At these companies, the wage differentials between regular and temporary agency workers were considerably smaller and the duration of temporary employment much shorter than at the other company, C.

Company $\mathrm{C}$, a foreign-owned subsidiary with a strong no-layoff commitment to its regular employees, paid high wages and benefits relative to its non-union competitors. With this strategy, it hoped to attract the best employees and avoid unionization. Its original rationale for hiring temporary workers was to buffer its regular employees in the event of a slowdown. However, the company expanded dramatically during the 1990s and began using temporary agencies to rapidly fill vacancies. Given that the hourly wage cost of agency temporaries was dramatically lower than that of regular employees, company executives had been reluctant to reduce temporary agency employment. The company hired exclusively through the agency, and temporaries had to wait six months to a year or more before they knew whether or not they would be offered a permanent position. Through temporary agencies, this company effectively lowered labor costs for new hires, thereby steepening the wage tenure profile and capturing economic rents from workers. 
Focus groups with regular associates and agency temporaries at this plant revealed that the temporaries felt the system, in which they were paid substantially lower wages for a long period of time before being offered a permanent job, was unfair. However, this resentment did not appear to adversely affect their productivity: they knew that they had to be extremely productive in order to gain permanent employment at the facility. The one negative impact on productivity from the recruitment policies at Company $\mathrm{C}$ came from high turnover. Many good workers grew tired of waiting for the offer of permanent employment and quit. Whether the adverse productivity effects from this high turnover outweighed the cost savings associated with lower wages was being debated internally at this company at the time of our interviews.

\section{CONCLUSION}

The share of employment in temporary help agencies grew steadily during the expansion of the 1990s. A consistent and striking finding from our case studies was that employers increasingly turned to temporary help agencies in tight labor markets largely because of difficulties in filling vacancies. Hospitals used temporary help agencies to staff high-skilled as well as low-skilled jobs. Employers in both sectors used temporary agencies to staff permanent as well as temporary positions.

We identify several potential advantages temporary agencies offer employers in recruiting workers. Especially in tight labor markets, temporary agencies likely enjoy economies-of-scale in recruiting and screening workers. By increasing the efficiency of job matches, temporary help agencies may reduce pressure on companies to raise wages in tight labor markets, thereby resulting in lower wage and higher employment growth. 
Additionally, we found evidence of substantial wage differentials between temp agency workers, on the one hand, and direct-hire temporaries and direct-hire permanent recruits, on the other, indicating other reasons why companies use agency temporaries in tight labor markets. In hospitals, our evidence strongly suggests that temporary help agencies were able to recruit nurses and other specialized clinical staff by paying them more than they would earn at the hospital. We argue that, by using temporary agency help, hospitals were able to raise the wages of new entrants without raising the wages of existing workers.

In contrast, we found little evidence of higher compensation among temporary workers assigned to lower-skilled positions in hospitals and we documented substantially lower compensation among temporary agency workers in production positions in auto supply companies. Rather than raising wages and trying to attract workers with good employment histories away from other companies, employers could use temporary help agencies to try out workers who, at least on average, were deemed more risky. We argue that temporary help agencies facilitated employers' use of riskier workers by lowering their compensation and the costs of dismissing and replacing them. In turn, temporary help agencies effectively expanded the supply of labor and mitigated the need for companies to raise wages for new and existing workers. In such cases, lower aggregate wages are observed both because risky workers with lower expected productivity and wages are utilized through temporary agencies and because employers are able to avoid wage increases for their existing workforce.

These three cost-saving benefits that temporary agencies potentially offer employers in tight labor markets-speedier job matching, wage discrimination in favor of new entrants, and lower costs of hiring risky workers-all would be expected to lower wage growth and increase employment growth in 
the aggregate economy. Katz and Krueger (1999) describe their empirical result linking temporary help employment to low wage growth as "speculative". Through detailed case studies we are able to better understand the mechanisms by which temporary help agencies may reduce pressure on employers to raise wages in tight labor markets and conclude that such a linkage is, indeed, plausible.

In closing, whether one can generalize from the results of these case studies to the aggregate economy is an open question. Nevertheless, the evidence from our case studies provides insights into the potentially important role temporary help employment plays in tight labor markets that warrants further study. 


\section{REFERENCES}

Abraham, Katharine G. 1988. "Flexible Staffing Arrangements and Employers' Short-term Adjustment Strategies." In Robert A. Hart, ed., Employment, Unemployment and Labor Utilization: 288-311. Boston: Unwin Hyman.

Abraham, Katharine G. 1990. "Restructuring the Employment Relationship: The Growth of MarketMediated Work Arrangements." In Katherine Abraham and Robert McKersie, eds., New Developments in the Labor Market: Toward a New Institutional Paradigm. 85-120. Cambridge, MA: MIT Press.

Anderson, Kay, and Barbara Wootton. 1991. "Changes in Hospital Staffing Patterns.” Monthly Labor Review (3): 9.

Autor, David. 2003. "Outsourcing at Will: Unjust Dismissal Doctrine and the Growth of Temporary Help Employment.” Journal of Labor Economics. (January).

Bellemore, Fred A. 1998. "Temporary Employment Decisions of Registered Nurses.” Eastern Economic Journal. 24 (3): 265-279.

Buerhaus, Peter I., Douglas O. Staiger, and David I. Auerbach. 2000. "Implications of an Aging Registered Nurse Workforce." Journal of the American Medical Association (283): 2948-2954.

Card, David, and Alan Krueger. 1995. Myth and Measurement: The New Economics of the Minimum Wage. Princeton, New Jersey: Princeton University Press.

Cohany, Sharon R. 1998. "Workers in Alternative Employment Arrangements: A Second Look." Monthly Labor Review 121(11): 3-21.

Davis-Blake, Alison, and Brian Uzzi. 1993. "Determinants of Employment Externalization: A Study of Temporary Workers and Independent Contractors." Administrative Science Quarterly 38(2): 195-223.

Doeringer, Peter B. and Michael Piore. 1971. Internal Labor Markets and Manpower Analysis. Lexington, MA: Heath.

Erickcek, George, Susan Houseman, and Arne Kalleberg. Forthcoming. "The Effects of Temporary Services and Contracting Out on Low-Skilled Workers." In [editors, book title.] New York: Russell Sage. 
Houseman, Susan. 2001a. "The Benefits Implication of Recent Trends in Flexible Staffing Arrangements." Working paper, The Pension Research Council, The Wharton School, University of Pennsylvania, WP 2001-19.

Houseman, Susan. 2001b. "Why Employers Use Flexible Staffing Arrangements: Evidence from an Employer Survey." Industrial and Labor Relations Review 55(1): 149-170.

Levine, David I., Dale Belman, Gary Charness, Erica L. Groshen, and K.C. O'Shaughnessy. 2002. How New is the "New Employment Contract"? Kalamazoo, MI: W.E. Upjohn Institute for Employment Research.

Kalleberg, Arne L., Jeremy Reynolds, and Peter V. Marsden. 2003. "Externalizing Employment: Flexible Staffing Arrangements in U.S. Organizations.” Social Science Research. In press.

Kandel, Eugene and Neil D. Pearson. 2001. "Flexibility versus Commitment in Personnel Management." Journal of the Japanese and International Economies, 15: 515-556.

Katz, Lawrence F., and Alan B. Krueger. 1999. "The High Pressure U.S. Labor Market of the 1990s." Brookings Papers on Economic Activity 1: 1-65.

Mangum, G., D. Mayall, and K. Nelson 1985. "The Temporary Help Industry: A Response to the Dual Internal Labor Market.” Industrial and Labor Relations Review 38: 599-611.

Schumacher, Edward J. 2001. "The Earnings and Employment of Nurses in an Era of Cost Containment.” Industrial and Labor Relations Review. 55(1): 116-132. 
Table 1 Use of Temporary Agency Help in Hospitals, by Occupation

\begin{tabular}{|c|c|c|c|c|}
\hline & & $\begin{array}{c}\text { Within } \\
\text { Occupations, } \% \\
\text { hours worked } \\
\text { by temps }\end{array}$ & $\begin{array}{l}\text { Distribution of temp } \\
\text { agency hours } \\
\text { across occupations } 1 \\
(\%)\end{array}$ & $\begin{array}{c}\text { Distribution of temp } \\
\text { agency bill across } \\
\text { occupations }{ }^{2} \\
(\%)\end{array}$ \\
\hline Hospital & Occupation & & & \\
\hline \multirow[t]{9}{*}{ M1 } & High-skilled clinical & & 35 & 59 \\
\hline & $\mathrm{RN}$ & 2 & 27 & 41 \\
\hline & Pharmacists and related occupations & 6 & 2 & 3 \\
\hline & Physical therapists & 3 & 6 & 15 \\
\hline & Low-skilled clinical & & & \\
\hline & Nursing \& medical assistants & 5 & 35 & 25 \\
\hline & Clerical/Administrative & & & \\
\hline & Unit administrative support & 7 & 30 & 17 \\
\hline & All Occupations & - & 100 & 100 \\
\hline \multirow[t]{7}{*}{ M2 } & Food service & 11 & 12 & 14 \\
\hline & Housekeeping & 5 & 18 & 9 \\
\hline & Clerical/Administrative & & 70 & 76 \\
\hline & Patient accounts & 10 & 6 & 9 \\
\hline & Admissions workers & 2 & 4 & 3 \\
\hline & Unit administrative support & 11 & 60 & 64 \\
\hline & All Occupations & - & 100 & 100 \\
\hline \multirow[t]{9}{*}{ NC1 } & High-skilled clinical & & 22 & 43 \\
\hline & $\mathrm{RN}$ & 0.7 & 10 & 20 \\
\hline & Imaging tech & 3 & 4 & 10 \\
\hline & LPN & 6 & 8 & 13 \\
\hline & Low-skilled clinical & & & \\
\hline & Nursing \& medical assistants & 4 & 20 & 17 \\
\hline & Clerical/Administrative & & & \\
\hline & Unit administrative support & 8 & 58 & 39 \\
\hline & All Occupations & - & 100 & 100 \\
\hline \multirow[t]{9}{*}{$\mathrm{NC2}^{3}$} & High-skilled clinical & & 80 & 92 \\
\hline & Certified $\mathrm{RN}$ anesthetist & 2 & 1 & 1 \\
\hline & $\mathrm{RN}$ & 4 & 42 & 49 \\
\hline & Imaging tech & 26 & 35 & 40 \\
\hline & Low-skilled clinical & & 17 & 7 \\
\hline & Nursing \& medical assistants & 7 & 14 & 6 \\
\hline & Clerical/Administrative & & & \\
\hline & Unit administrative support & 0.4 & 3 & 1 \\
\hline & All Occupations & - & 100 & 100 \\
\hline
\end{tabular}


Table 1 (Continued)

\begin{tabular}{|c|c|c|c|c|}
\hline & & $\begin{array}{c}\text { Within } \\
\text { Occupations, } \% \\
\text { hours worked } \\
\text { by temps }\end{array}$ & $\begin{array}{l}\text { Distribution of temp } \\
\text { agency hours } \\
\text { across occupations } 1 \\
(\%)\end{array}$ & $\begin{array}{c}\text { Distribution of temp } \\
\text { agency bill across } \\
\text { occupations }{ }^{2} \\
(\%)\end{array}$ \\
\hline Hospital & Occupation & & & \\
\hline \multirow[t]{8}{*}{ NC3 } & High-skilled clinical & \multirow{3}{*}{0.1} & & \\
\hline & $\mathrm{RN}$ & & 7 & 19 \\
\hline & Low-skilled clinical & & 81 & 71 \\
\hline & Phlebotomists & 0.7 & 1 & 1 \\
\hline & Nursing \& medical assistants & 2 & 80 & 70 \\
\hline & \multicolumn{4}{|l|}{ Clerical/Administrative } \\
\hline & Unit administrative support & 0.3 & 12 & 10 \\
\hline & All Occupations & - & 100 & 100 \\
\hline
\end{tabular}

${ }^{1}$ Figures in this column report the percent of total temp agency hours worked in a hospital accounted for by each occupation.

${ }^{2}$ Figures in this column report the percent of a hospital's total temporary agency bill accounted for by each occupation.

${ }^{3}$ Occupations that account for less than 1 percent of the hospital's expenditures on temporary agencies are not listed separately but are included in hospital subtotals in columns 2 and 3. 
Table 2 Comparison of Hourly Cost of Full-Time Employees and Agency Temporaries in Hospitals, by Occupation

\begin{tabular}{|c|c|c|c|c|}
\hline & & $\begin{array}{l}\text { Average total cost } \\
\text { full-time (\$) }\end{array}$ & $\begin{array}{l}\text { Bill rate agency } \\
\text { temporaries (\$) }\end{array}$ & $\begin{array}{l}\% \text { difference, } \\
\text { agency temps } \mathrm{v} . \\
\text { employees }\end{array}$ \\
\hline Hospital & Occupation & & & \\
\hline \multirow[t]{8}{*}{ M1 } & High-skilled clinical & & & \\
\hline & RN & 27.51 & 34.25 & 24 \\
\hline & Pharmacists and related occupations & 26.51 & 27.40 & 3 \\
\hline & Physical therapists & 25.56 & 53.77 & 110 \\
\hline & Low-skilled clinical & & & \\
\hline & Nursing \& medical assistants & 13.23 & 15.50 & 17 \\
\hline & Clerical/Administrative & & & \\
\hline & Unit administrative support & 14.34 & 12.92 & -10 \\
\hline \multirow[t]{6}{*}{ M2 } & Food service & 12.90 & 10.88 & -16 \\
\hline & Housekeeping & 11.27 & 10.94 & -3 \\
\hline & Clerical/Administrative & & & \\
\hline & Patient accounts & 15.33 & 17.02 & 11 \\
\hline & Admissions workers & 14.48 & 13.32 & -8 \\
\hline & Unit administrative support & 13.94 & 14.74 & 6 \\
\hline \multirow[t]{8}{*}{$\overline{\mathrm{NC1}}$} & High-skilled clinical & & & \\
\hline & $\mathrm{RN}$ & 24.25 & 34.12 & 41 \\
\hline & Imaging tech & 22.32 & 36.05 & 62 \\
\hline & LPN & 16.67 & 28.15 & 69 \\
\hline & Low-skilled clinical & & & \\
\hline & Nursing \& medical assistants & 12.16 & 14.86 & 22 \\
\hline & Clerical/Administrative & & & \\
\hline & Unit administrative support & 13.29 & 11.48 & -14 \\
\hline \multirow[t]{8}{*}{$\mathrm{NC2}^{1}$} & High-skilled clinical & & & \\
\hline & Certified RN anesthetist & 55.12 & 60.00 & 9 \\
\hline & RN & 27.82 & 40.00 & 44 \\
\hline & Imaging tech & 23.69 & 40.00 & 69 \\
\hline & Low-skilled clinical & & & \\
\hline & Nursing \& medical assistants & 12.07 & 14.68 & 22 \\
\hline & Clerical/Administrative & & & \\
\hline & Unit administrative support & 16.09 & 11.50 & -29 \\
\hline \multirow[t]{7}{*}{$\overline{\mathrm{NC3}}$} & High-skilled clinical & & & \\
\hline & $\mathrm{RN}$ & 26.31 & 36.25 & 38 \\
\hline & Low-skilled clinical & & & \\
\hline & Phlebotomists & 14.97 & 16.75 & 12 \\
\hline & Nursing \& medical assistants & 13.58 & 12.25 & -10 \\
\hline & Clerical/Administrative & & & \\
\hline & Unit administrative support & 14.58 & 11.50 & -21 \\
\hline
\end{tabular}

${ }^{1}$ Occupations that account for less than 1 percent of the hospital's expenditures on temporary agencies are not listed. 


\section{Table 3 Use of Temporary Agency Employment among Auto Suppliers}

\begin{tabular}{|c|c|c|c|c|c|c|c|}
\hline \multirow[b]{2}{*}{ Company } & \multirow[b]{2}{*}{ Product } & \multirow[b]{2}{*}{ Organization type } & \multirow[b]{2}{*}{ Union } & \multirow[b]{2}{*}{$\begin{array}{c}\text { All } \\
\text { employees }\end{array}$} & \multirow[b]{2}{*}{$\begin{array}{l}\text { Production } \\
\text { employees }\end{array}$} & \multicolumn{2}{|c|}{ Temporary employees } \\
\hline & & & & & & Number & $\begin{array}{c}\text { As percent of all } \\
\text { production } \\
\text { employment }\end{array}$ \\
\hline A & $\begin{array}{l}\text { Technically advanced interior } \\
\text { and exterior equipment }\end{array}$ & Locally owned & No & 1,400 & 1,000 & $30-60$ & $5-6$ \\
\hline $\mathrm{B}$ & Chassis systems & $\begin{array}{l}\text { European-owned } \\
\text { branch plant }\end{array}$ & No & 750 & 450 & 125 & 28 \\
\hline $\mathrm{C}$ & $\begin{array}{l}\text { Heat exchange } \\
\text { component parts }\end{array}$ & Japanese subsidiary & No & 2,100 & 1,521 & 348 & $23-25$ \\
\hline $\mathrm{D}$ & Drive shafts & $\begin{array}{l}\text { Branch plant of large U.S. } \\
\text { owned company }\end{array}$ & Yes & 900 & 550 & 0 & 0 \\
\hline $\mathrm{E}$ & Auto body components & $\begin{array}{l}\text { Locally owned single } \\
\text { plant company }\end{array}$ & Yes & 430 & 320 & $0-30^{1}$ & $0-9$ \\
\hline
\end{tabular}

${ }^{1}$ This plant had recently laid off all 30 of its temporary workers. 
Table 4 Cost Comparisons of Permanent and Temporary Workers

\begin{tabular}{cccccc}
\hline Company & $\begin{array}{c}\text { Hourly wage } \\
\text { temporaries (\$) }\end{array}$ & $\begin{array}{c}\text { Bill rate } \\
\text { temporaries (\$) }\end{array}$ & $\begin{array}{c}\text { Starting wage } \\
\text { employees (\$) }\end{array}$ & $\begin{array}{c}\text { Total hourly costs } \\
\text { employees (\$) }\end{array}$ & $\begin{array}{c}\text { \% difference, hourly cost } \\
\text { agency temps v. } \\
\text { employees }\end{array}$ \\
\hline A & 7.90 & 10.90 & 10.60 & 13.78 & $! 21$ \\
B & 8.00 & 10.40 & 9.62 & 12.51 & $! 17$ \\
C & 7.50 & 10.88 & 13.28 & 18.22 & $! 40$ \\
D & - & - & 15.51 & 30.51 & - \\
E & 12.35 & 16.92 & 12.35 & 22.85 & $! 26$ \\
\hline
\end{tabular}

